\title{
Dose of Paclobutrazol in the Growth of Sugarcane Seedlings in Vitro in the Acclimatization Stage
}

\section{Tomás Díaz Valdés, Leopoldo Partida Ruvalcaba*, Felipe Ayala Tafoya, Carlos Alfonso López Orona, Teresa de Jesús Velázquez Alcaraz}

Faculty of Agronomy of the Autonomous University of Sinaloa, Culiacán, México

Email: *parpolo@yahoo.com.mx

How to cite this paper: Valdés, T.D., Ruvalcaba, L.P., Tafoya, F.A., Orona, C.A.L. and de Jesús Velázquez Alcaraz, T. (2017) Dose of Paclobutrazol in the Growth of Sugarcane Seedlings in Vitro in the Acclimatization Stage. Agricultural Sciences, 8, 751-758.

https://doi.org/10.4236/as.2017.88056

Received: July 5, 2017

Accepted: August 15, 2017

Published: August 18, 2017

Copyright $\odot 2017$ by authors and Scientific Research Publishing Inc. This work is licensed under the Creative Commons Attribution International License (CC BY 4.0).

http://creativecommons.org/licenses/by/4.0/

\begin{abstract}
Micropropagation has been widely used for the rapid multiplication of many plant species, where the final quality of the plant depends on the acclimatization stage. To obtain compact plants, with desired characteristics and adaptable to field conditions, the use of chemical inhibitors of growth is necessary. In sugarcane of the variety CP 72-2086 the effects caused by the growth regulator paclobutrazol (PBZ) in vitro plants applied in the acclimatization phase are unknown. The objective of this research was to know the effect of paclobutrazol in the acclimatization phase in the growth and development of the vitro plants of sugarcane of the variety CP 72-2086. The research was carried out in the greenhouse of the Faculty of Agronomy of the Autonomous University of Sinaloa, located at $24^{\circ} 37^{\prime} 29^{\prime \prime} \mathrm{N}$ and $107^{\circ} 26^{\prime} 36^{\prime \prime} \mathrm{W}$, in Sinaloa, Mexico. Micro-propagated sugarcane seedlings were used by tissue culture; vitro plants were extracted from the flasks 24 hours before being transplanted into the greenhouse. The treatments of PBZ applied were the doses of 0 (control), $100,150,200,250$ and $300 \mathrm{mg} \cdot \mathrm{L}^{-1}$. The PBZ was applied when the seedlings had seven true leaves [( 31 days after transplant (ddt)], and did not show gutting. At $36 \mathrm{ddt}$, the vitro plants of the trays were extracted and the variables evaluated were height $(\mathrm{cm})$, stem diameter $(\mathrm{mm})$, root length $(\mathrm{cm})$, root volume $(\mathrm{mL})$, root dry weight $(\mathrm{g})$, aerial biomass dry weight $(\mathrm{g})$, leaf area $\left(\mathrm{cm}^{2}\right)$ and greenness in spad units. A randomized complete block design with three replicates was used. The results of the study indicated that the dose of 150 $\mathrm{g} \cdot \mathrm{L}^{-1}$ of PBZ induced the growth of plants more compact and of better quality for the transplant.
\end{abstract}

\section{Keywords}

CP 72-2086, Micropropagation, Spad Units, Root Volume, Stem Diameter 


\section{Introduction}

Micropropagation has been widely used for the rapid multiplication of many plant species, but their more widespread use is limited by a high percentage of plants lost or damaged when transferred to greenhouse or field conditions [1].

The process of acclimatization of plants grown in vitro proves to be one of the most important phases in a biofactory, when the sugarcane plantlet is extracted from the laboratory to the greenhouses for the acclimatization, the change to different environmental conditions has the consequence that these are very susceptible to different stress, because they have not developed or have not adapted their organs to the new conditions, so they need to respond with new anatomical, morphological and physiological characteristics [1] [2] [3] [4].

The final quality of the plants produced by micropropagation depends on the acclimatization stage [2]. In this phase, different substances and microorganisms have been tested in order to reduce losses and improve the quality of plants [3] [5]. For the survival of plants must be made that these are compact with appropriate growth of the root system and leaf area [2]. The production of compact plants with characteristics that are desirable and adaptable to the field conditions necessitates the use of chemical growth inhibitors that possess qualities to handle the size and the natural form of plants in a relatively short time [6]. The use of growth regulators, such as paclobutrazol (PBZ), leads to retarding growth, decreasing height and, consequently, making compact plants, due to the inhibition of gibberellic acid synthesis [6] [7].

However, since there is currently no record of the effect of PBZ on the quality of vitro plants of sugarcane, variety CP 72-2086, applied in the phase of acclimatization of seedlings for field transplantation, the objective of this research was to know the response in growth and development of said plants after applying the PBZ in the mentioned phase.

\section{Materials and Methods}

The research was carried out in a greenhouse of the Faculty of Agronomy of the Autonomous University of Sinaloa, located at $24^{\circ} 37^{\prime} 29^{\prime \prime} \mathrm{N}$ and $107^{\circ} 26^{\prime} 36^{\prime \prime} \mathrm{W}$, in Sinaloa, Mexico. Sugarcane seedlings of the variety CP 72-2086 were micropropagated by tissue culture. The vitro plants were extracted from the flasks 24 hours before being transplanted into the greenhouse, separated by size and rinsed to remove residues from culture media. Rooted seedlings were transplanted on November 22, 2013, in polypropylene trays with 54 holes filled with peat moss (organic peat) and $32 \mathrm{~cm}^{3}$ capacity. In this phase of acclimatization, the vitro plants were kept for 38 days after transplant (ddt), in the greenhouse that had the conditions of humidity, light and temperature required for the growth and development of plants.

With microspring the plants were irrigated until $36 \mathrm{ddt}$ with a duration of 1.5 minutes every 4 hours for seven days, and during the other 29 days the duration of the irrigations was 2.0 minutes every 8 hours. Three Nitrogen $(\mathrm{N})$ applications 
were made from lobby urea $(44 \% \mathrm{~N})$, using an aqueous solution of $2.2 \mathrm{~g} \cdot \mathrm{L}^{-1}$ of $\mathrm{N}$. The doses of PBZ applied were 0 (control), 100, 150, 200, 250 and $300 \mathrm{mg} \cdot \mathrm{L}^{-1}$. Each dose was applied only once with a hand-held atomiser. In order to avoid contamination, an atomizer was used for each treatment. The solution was sprayed with the same number of shots (7) of the atomizer in each experimental unit, and each shot was attempted to be carried out with almost the same force, until dew-like droplets were formed on the surface of the leaves of the seedlings, without that these droplets had fallen; distilled water was applied to the control seedlings. The PBZ was applied when the seedlings had seven true leaves (31 ddt) without gutation by bundle. The already sprayed seedlings were isolated by glass barriers in order not to contaminate the rest of the experimental units.

For statistical analysis, a randomized complete block design with three replicates was used; each tray represented an experimental unit with 54 seedlings per tray, evaluating 10 of them randomly. At $36 \mathrm{ddt}$, the vitro plants of the trays were extracted and they were determined the variables of plant height $(\mathrm{cm})$, stem diameter $(\mathrm{mm})$, roots length $(\mathrm{cm})$, roots volume $(\mathrm{mL})$, roots dry weight $(\mathrm{g})$, dry weight of biomass aerial $(\mathrm{g})$, leaf area $\left(\mathrm{cm}^{2}\right)$ and greenness in spad units. The height of plants was measured from the base of the stem to the apex of the last expanded leaf; The stem diameter was measured with a vernier, the volume of roots was determined by the displacement of water through a graduated cylinder, the root dry matter and aerial part was obtained in stove at $70^{\circ} \mathrm{C}$ for $48 \mathrm{~h}$ until constant weight, and its weight was determined with digital scale. With the statistical package SAS Institute [8], analyzes of variance and comparison of means were made with the Tukey test at 0.05 .

\section{Results and Discussion}

\subsection{Plant Height}

Was no detect significant effect of the PBZ on plant height (Figure 1), numerically the control was superior to PBZ-treated plants, the results show a tendency to decrease plant height by increasing PBZ concentration; Similar results were obtained by Chacón et al. [9] in the species Dioscorea trifida and D. alata, where no significant differences were observed between the effects caused by the treatments in the growth of the seedlings during the acclimatization process due to the addition of paclobutrazol to the crop and with a linear relationship inverse between height and dose of PBZ. The observed effect of this triazole is that it slows growth because it inhibits the biosynthesis of gibberellin, which affects cell elongation, resulting in more compact plants (Chacon et al. [9]; Chaney [10].

\subsection{Stem Diameter}

In the stem diameter of the in vitro sugarcane seedlings treated with PBZ, it was observed that this was higher than in the control (Figure 2), where the 150 $\mathrm{mg} \cdot \mathrm{L}^{-1}$ dose caused an increase of $15.1 \%$ with respect to the control. The effect of PBZ on tomato stem thickness has been reported by Berova and Zlatev [11] after 


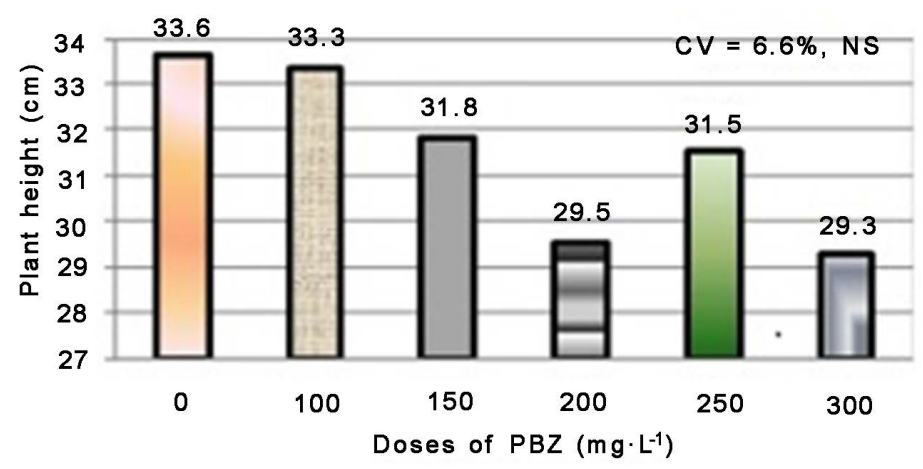

Figure 1. Effect of Paclobutrazol on the height of sugarcane seedlings (Saccharum sp.) in vitro in the acclimatization phase. (NS: Nonsignificant difference).

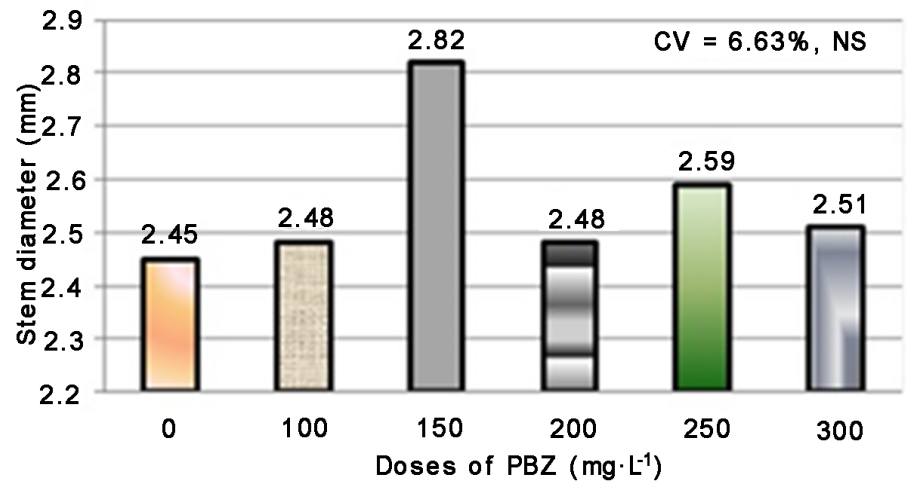

Figure 2. Effect of Paclobutrazol on the stem diameter of sugarcane seedling (Saccharum sp.) in vitro in the acclimatization phase. (NS: Non-significant difference).

applying it on the foliage in solution of $25 \mathrm{~g} \cdot \mathrm{L}^{-1}$, likewise by Giovinazzo et al. [12] with an increase of $9.0 \%$.

\subsection{Roots Length}

The analysis of variance indicated highly significant differences in roots length ( $\mathrm{p}<0.01)$, so that with Tukey's test $(\alpha=0.05)$ it was detected that the effect caused by the doses of 150 and $250 \mathrm{mg} \cdot \mathrm{L}^{-1}$ of PBZ was statistically the same, but higher than those observed in the control plants and in those treated with 100, 200 or $300 \mathrm{mg} \cdot \mathrm{L}^{-1}$. With 150 and $250 \mathrm{mg} \cdot \mathrm{L}^{-1}$ the increments respective were 9.9 and $17.7 \%$ relative to the control (Figure 3). Similar results were obtained by Bello-Bello et al. [7] after applying solution with $2 \mathrm{mg} \cdot \mathrm{L}^{-1}$ of PBZ.

\subsection{Roots Volume}

This response variable was expressed without significant statistical differences between the averages obtained with the different doses of PBZ and the control (Figure 4); however, with $150 \mathrm{mg} \cdot \mathrm{L}^{-1}$ an increase of $36.1 \%$ was achieved in comparison to the control. These results are closely related to those of Partida-Ru- 


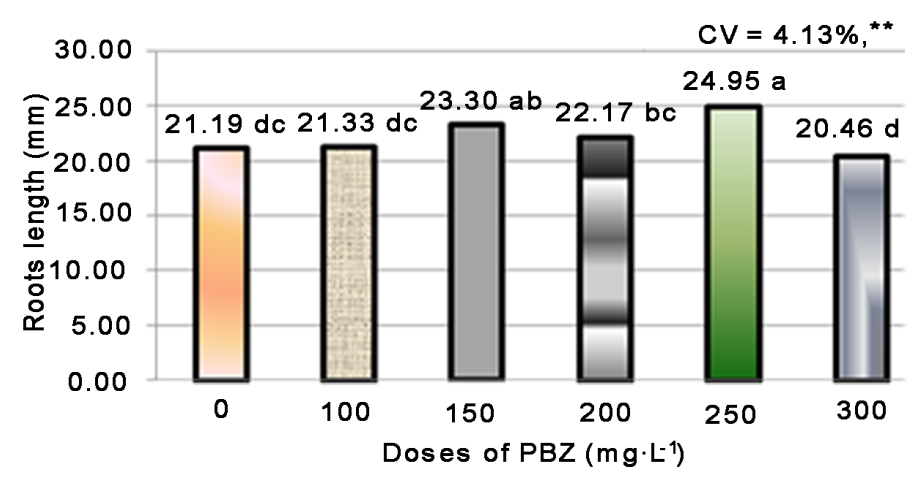

Figure 3. Effect of Paclobutrazol on the root length of the sugarcane seedling (Saccharum sp.) in vitro in the acclimatization phase. (NS: Non-significant difference).

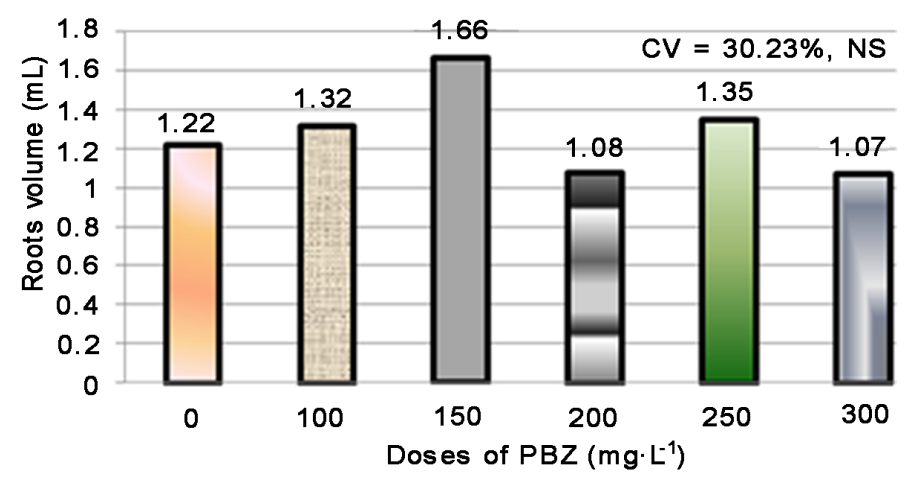

Figure 4. Effect of Paclobutrazol on roots volume of sugarcane seedling (Saccharum sp.) in vitro in the acclimatization phase. (NS: Nonsignificant difference).

valcaba et al. [13], since they reported that with $150 \mathrm{mg} \cdot \mathrm{L}^{-1}$ of PBZ the root system was increased in seedlings of bell pepper and eggplant.

\subsection{Weight Dry of Roots}

This other study variable was also expressed without statistical differences between the means that induced the different doses of PBZ and the control (Figure 5); however, with $150 \mathrm{mg} \cdot \mathrm{L}^{-1}$ it was have an increase of $15.0 \%$ with respect to the control. These results are also closely related to those of Partida-Ruvalcaba et al. [13], mentioned in the previous paragraph.

\subsection{Dry Weight of Biomass Aerial}

The PBZ did not significantly affect this variable in comparison to the control (Figure 6), but in absolute values the highest production was presented in seedlings that received 150 or $200 \mathrm{mg} \cdot \mathrm{L}^{-1}$, whose averages exceeded in $10 \%$ that was obtained in the control. Similar trends observed Partida-Ruvalcaba et al. [13] in seedlings of bell pepper and eggplant cultivated with $150 \mathrm{mg} \cdot \mathrm{L}^{-1}$ of PBZ in the solution applied on the foliage. 


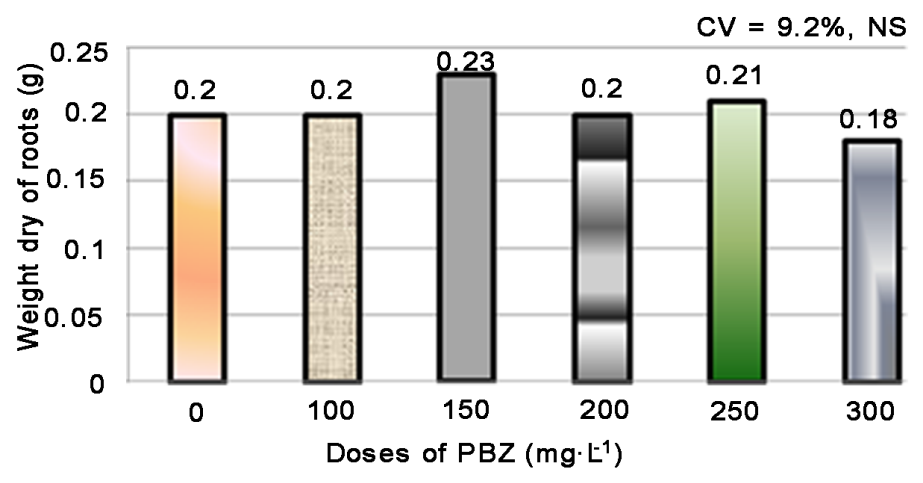

Figure 5. Effect of Paclobutrazol on roots dry weight of sugarcane seedling (Saccharum sp.) in vitro in the acclimatization phase. (NS: Non-significant difference).

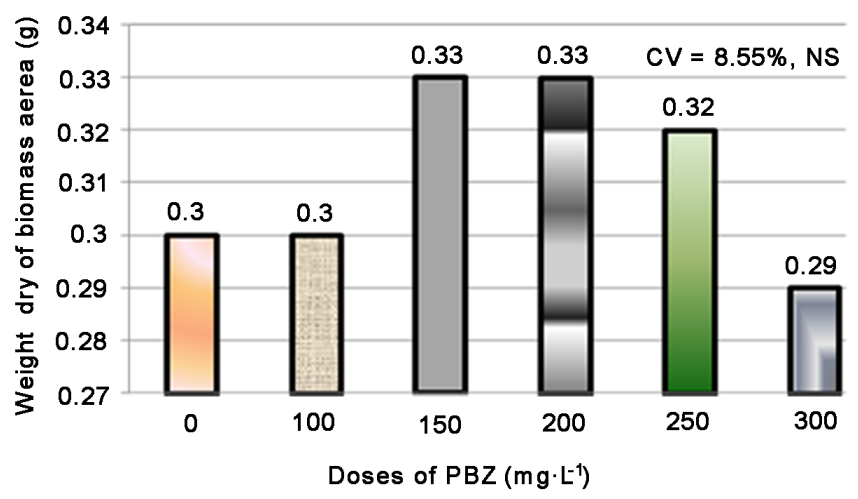

Figure 6. Effect of paclobutrazol on dry weight of biomass aerial of sugarcane seedling (Saccharum sp.) in vitro in the acclimatization phase. (NS: Non-significant difference).

\subsection{Leaf Area}

In this other characteristic of the seedlings, no significant statistical differences were observed between the average values that induced PBZ doses in relation to the control (Figure 7), but with $150 \mathrm{mg} \cdot \mathrm{L}^{-1}$ of PBZ the seedlings had an increase of $7.7 \%$ compared with control, although with 100,250 and $300 \mathrm{mg} \cdot \mathrm{L}^{-1}$ the tendency was to decrease. The increase caused by the $150 \mathrm{mg} \cdot \mathrm{L}^{-1}$ is related to what was discovered by Silva et al. [14] in sunflower plants cultivated with $31 \mathrm{mg} \cdot \mathrm{L}^{-1}$ in the solution applied twice in the foliage, resulting in an increase of $5.3 \%$ of leaf area with respect to the control.

\subsection{Greenness}

This character varied in a range of 26.1 to 30.7 and the analysis of variance indicated highly significant differences between the values achieved in the PBZ treated seedlings and the control, so that the Tukey test $(\alpha=0.01)$ established that the greenness was higher in the order of the solutions with 200,300, 250, 150 and $100 \mathrm{mg} \cdot \mathrm{L}^{-1}$ applied leaf (Figure 8) compared to the control seedlings. 


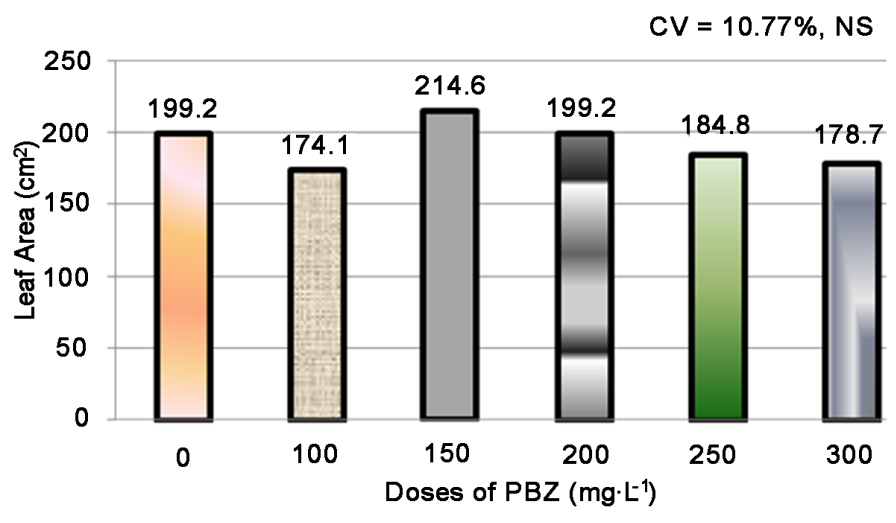

Figure 7. Effect of Paclobutrazol on the leaf area of sugarcane seedlings (Saccharum sp.) in vitro in the acclimatization phase. (NS: Non-significant difference).

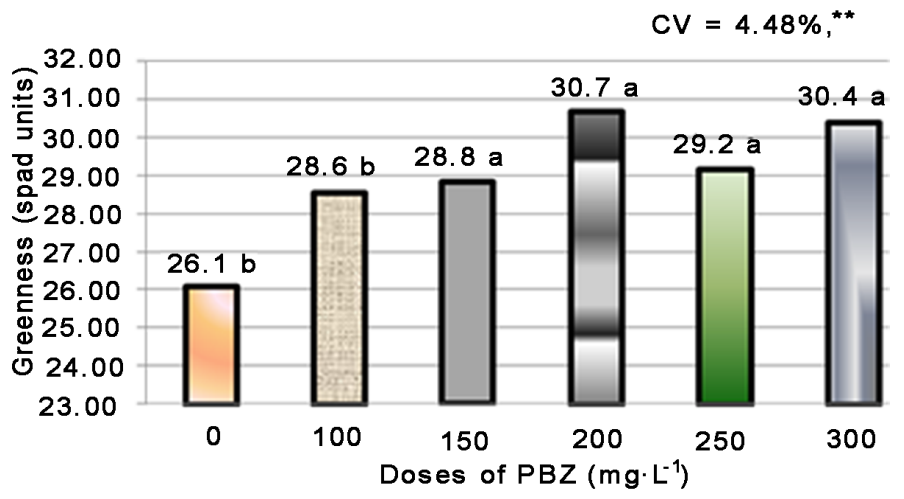

Figure 8. Effect of paclobutrazol in the greenness of sugarcane seedlings (Saccharum sp.) in vitro during the acclimatization phase. (**Highly significant difference).

\section{Conclusion}

Paclobutrazol caused a reduction in plant height; the dose of $150 \mathrm{mg} \cdot \mathrm{L}^{-1}$ promoted a greater growth of stem diameter, root volume, root dry matter and aerial part and greenness, so that this growth regulator, applied in the acclimatization phase, induces the production of seedlings of sugarcane in vitro with quality and greater probability of success since the transplant in field.

\section{References}

[1] Pospíšilová, J., Tichá, I., Kadleček, P., Haisel, D. and Plzáková, Š. (1999) Acclimatization of Micropropagated Plants to ex Vitro Conditions. Biologia Plantarum, 42, 481-497. https://doi.org/10.1023/A:1002688208758

[2] Díaz, L.P., Namur, J.J., Bollati, S.A. and Arce, O.E.A. (2010) Acclimatization of Phalaenopsis and Cattleya Obtained by Micropropagation. Revista Colombiana de Biotecnología, 12, 27-40.

[3] Reyes, C.F., Rivera, O., Jiménez, M., Montes de Oca, J.L., Occeguera, Z., Hernández, A.R., García, J.R. and Martínez, S. (2011) Aclimatización de cultivares de caña de azúcar procedentes de la fase de enraizamiento a los que se les aplicó Fitomas-E. 
Centro Agrícola, 38, 11-14.

[4] Sánchez-Rodríguez, L.Á., Saavedra-Hortúa, D. and Mauricio-Romero, H. (2012) Aclimatación y endurecimiento de materiales de palma de aceite obtenidos mediante técnicas de cultivo de tejidos vegetales. Revista Palmas, 33, 41-52.

[5] Rodríguez, R., Escalona, M., Rodríguez, Y., Cid, M. and González-Olmedo, J.L. (2000) Aclimatización de plántulas de caña de azúcar (Saccharum sp. híbrido) proveni-entes de sistemas de inmersión temporal. Cultivos Tropicales, 21, 51-56.

[6] Pichardo-Ruiz, F.D., Villegas-Monter, Á., Hernández-Livera, A. and Colinas-León, M.T. (2003) Cambios morfológicos en plantas De dalia (Dahlia pinnata Cav.) Tratadas con Paclobutrazol. Revista Chapingo Serie Horticultura, 9, 151-161. https://doi.org/10.5154/r.rchsh.2001.02.010

[7] Bello-Bello, J., Poot-Poot, W., Iglesias-Andreu, L., Caamal-Velázquez, H. and DiazSanchez, M.C. (2014) Comparación del efecto de osmorreguladores e inhibidores del crecimiento en la conservación in Vitro de caña de azúcar. Agrociencia, 48, 439-446.

[8] SAS Institute (1996) SAS User's Guide: Basics. 5th Edition, SAS Institute Inc., Cary, 1181-1191.

[9] Chacón, A.G., Gómez, L., Torres, S. and Saborío, F. (2005) Aclimatización de plántulas de yampí (Dioscorea trifida) y ñame (D. alata) producidas in Vitro. Agronomía Costarricense, 29, 47-58.

[10] Chaney, W.R. (2005) Growth Retardants: A Promising Tool for Managing Urban Trees. Purdue Extension Document FNR-252-W. http://www.extension.purdue.edu/extmedia/FNR/FNR-252-W.pdf

[11] Berova, M. and Zlatev, Z. (2000) Physiological Response and Yield of Paclobutrazol Treated Tomato Plants (Lycopersicon esculentum Mill.). Plant Growth Regulation, 30, 117-123. https://doi.org/10.1023/A:1006300326975

[12] Giovinazzo, R., Souza, M.V. and Hartz, T.K. (2001) Paclobutrazol Responses with Processing Tomato in France. Acta Horticulturae, 542, 355-358. https://doi.org/10.17660/ActaHortic.2001.542.46

[13] Partida-Ruvalcaba, L., Velázquez-Alcaraz, T.J., Acosta-Villegas, B., Ayala-Tafoya, F., Díaz-Valdés, T., Inzunza-Castro, J.F. and Cruz-Ortega, J.E. (2007) Paclobutrazol y crecimiento de raíz y parte aérea de plántulas de pimiento morrón y berenjena. Revista Fitotecnia Mexicana, 30, 145-149.

[14] Silva, G.M, Gámez, G.H., Zavala, G.F., Cuevas, H.B. and Rojas, G.M. (2001) Efecto de cuatro fitorreguladores comerciales en el desarrollo y rendimiento del girasol. Ciencia $U A N L, 4,69-75$. 
Submit or recommend next manuscript to SCIRP and we will provide best service for you:

Accepting pre-submission inquiries through Email, Facebook, LinkedIn, Twitter, etc. A wide selection of journals (inclusive of 9 subjects, more than 200 journals)

Providing 24-hour high-quality service

User-friendly online submission system

Fair and swift peer-review system

Efficient typesetting and proofreading procedure

Display of the result of downloads and visits, as well as the number of cited articles Maximum dissemination of your research work

Submit your manuscript at: http://papersubmission.scirp.org/

Or contact as@scirp.org 